\title{
RADICAL LEFT IN ALBANIA AND KOSOVO: DIFFERENCES AND SIMILARITIES
}

\section{Klejd Këlliçi \\ University of Tirana,k.kellici@gmail.com}

Emira Danaj

University of Neuchatel,ermira.danaj@unine.ch

DOI: $10.1515 /$ seeur-2017-0002

\section{Abstract}

The main research question for this paper is: Are there radical left wing movements in Albania and Kosovo and what are their main traits? Through answering this question, we will explore the development (or lack thereof) of radical left wing movements. With radical left we intend movements that reject the underlying socio-economic structure of contemporary capitalism and its values and practices without opposing democracy. Through a thorough desk research and several interviews with experts and activists both in Albania and Kosovo, we look at the two case Political Opportunity Structures to study the emergence, the strategies, success or failures of the radical left. In Albania the radical left has been in decline since 1992, with only a recent revival from 2009 on. In Kosovo, the Lëvizja Vetëvendojse! (Self-Determination Movement), a civil movement transformed in a party, has succeeded in imposing its left agenda. Both cases employ a new rhetoric unrelated to the past communist regimes thus changing the perspective of political debate in both countries.

Key words: political parties, radical left, Albania, Kosovo, Vetëvendosje

Short title: Radical Left in Albania and Kosovo. 


\section{Introduction $^{1}$}

The main research question for this paper is: Are there radical left wing movements in Albania and Kosovo and what are their main traits? Through answering this question, we will explore the development (or lack thereof) of radical left wing movements in Albania and Kosovo after the 1990 changes in the political system.

To define radical left we refer to March and Mudde (2005:25): " [...] 'radical left', which is radical first in that it rejects the underlying socio-economic structure of contemporary capitalism and its values and practices (ranging from rejection of consumerism and neoliberalism to outright opposition to private property and capitalistic profit incentives)."2

The fall of communism in Albania occurred in 1991. The introduction through shock therapy capitalism exposed the population to massive unemployment and ruined the industrial base of the country (De Waal 2005:10). In 1991, the old Labor Party held a Congress of transformation, changing its name to the Socialist Party of Albania and embracing the principles of a multiparty system, market economy, etc. Until 2009 the Socialist Party has had a trajectory of distancing from the left and shifting to the centre (this was not the case of the right wing Democratic Party). After losing the elections of 2009 and before the last elections of 2013, the Socialist Party started to come back to the left ideas by building its 'battle horse' over the progressive tax policies. Since 2009, left-wing voices, especially those coming from academics or students have been accentuated in Albania, such as for instance Antonio Gramsci Institute, The Political Organisation (OP), Occupy Tirana, etc. The majority of these new "organizations" are of a Marxist identification. The main issues for them are anti-neoliberalism, anti-fascism and social protest (similar to some young leftist organisations in the region) (Kanzleiter and Tomic 2012) but with a weak feminist perspective.

At the same time, the situation in Kosovo proves to be similar as well as different to the Albanian one. However, the difference is in the stronger articulation

\footnotetext{
${ }^{1}$ We would like to thank for their invaluable collaboration and support, the experts, scholars and activists that contributed this paper through their interviews, comments and feedbacks: Ajkuna Hoppe, Arber Zaimi, Ermal Hasimja, Elvin Gjevori, Koco Danaj, Klementin Mile and Jani Marka, and also those persons who asked to remain anonymous.

${ }^{2}$ In the recent political context of Western (but also Eastern) Europe and United States, where most of the so called left parties have shifted toward a more central and undefined ideological program, 'radical left' appears to match with what left represented previously to this ideological shift.
} 
of a proper left wing program of the Self-determination Movement (Lëvizja Vetëvendosje! ${ }^{3}$ ). This movement that dates back to 2005 , currently holds $12 \%$ of the seats of the Parliament of Kosovo and it is almost the only Albanian political structure with a well-defined and clear program focussing on social welfare, on the importance of the public good, fighting mass-privatisation in Kosovo, etc.

The paper draws from a critical review of the literature and previous studies on left-wing parties/organisations and political parties in Albania and Kosovo, in the former communist countries, but also theoretical works on left/radical left developments. We have also used newspaper articles and interviews (online and printed) regarding political parties/movements being of high relevance for our analysis. For the purpose of this paper, we have conducted six interviews with experts and activists. Because of the physical impossibility of conducting face to face semi-structured in depth interviews, we opted for structured interviews. We contacted the experts and activists via email, and sent them the structured interview. The interviewed persons were selected according to the purposive sampling, as we intended to interview knowledgeable persons regarding left/radical left in Albania and Kosovo in order to have a very qualitative and up to date information and analysis. According to Morse (1998, p.73 in Flick, 2009, p. 123) we selected the interviewees based on the criteria of having the necessary knowledge and experience to answer the questions of the interview. Our interviewees are activists in radical/left wing movements and organisations, and experts of political sciences, sociology and anthropology. The paper is built following this structure: the first part engages in a theoretical discussion of the radical left and political opportunity structure. The second part tries to give a contextual outlook of the two cases taken in consideration while the third part engages in the study of left radicalism in Kosovo and Albania

\section{Theoretical Background}

Differences between the radical left and the left are anyway predictable since the social base which 'feeds' the left is different in both areas. March states that the basic difference, in terms of left and radical left, between East and Western Europe is the social basis. While in the European West, the left had problems with the change of the social basis, in the East, this was missing as a result of economic reforms (March 2008). This might be true in either

\footnotetext{
${ }^{3}$ We will use Lëvizja Vetëvendosje and Vetëvendosje (the shortened version of the name) interchangeably
} 
of the cases we take under consideration. In Albania, the so called 'shock therapy' reforms have erased the industrial base of the country, destroying also the possibility of former social organizations such as trade unions to be perpetuated in the new post-communist regime. Since then, the trade unions became quasi non-existent entities in Albania. On the other hand, the trade union movement in Kosovo was at the front line of the process aimed at peacefully opposing the Milosevic regime in the early nineties, but it did not retain its importance after the NATO intervention and recent independence. Under these circumstances the left has failed to provide a viable connection with what is perceived to be its normal base of power. This difficulty has been also underlined by Mair (1997) which states that political party system in Eastern Europe is quite different from that of the West, in terms of democratization process, or to what has been earlier described as triple or quadruple transition (Offe 1991). Secondly, Mair (1997:181) focuses on the difference of party organization and electoral processes with weak cleavage structure and prone to instability and the structure of competition. To this latter element Mair attributes some importance stating that Eastern Europe party systems are more open and prone to changes over time, which in turn does not let the electorate to stabilize over time. It underlines some kind of facility for new groups, movements or parties to emerge. While this has been partly true for Kosovo with the emergence of Vetëvendosja, the Albanian case is somehow different. The Albanian party system has retained some degree of stability over time with few actors contesting elections and stable governments or coalitions (Krasniqi 2009; Stoyarova 2010: 182).

In many cases the leitmotiv of political discourse in Albania has been characterized by a strong reference to leading ideological families of left and right. Even discourse on matters such as anticorruption, a basic discursive feature in the electoral campaigns in Albania, has been based on the respective 'failure' of economic models adopted by the left and the right (Kajsiu 2008; Këlliçi 2010). In Kosovo such a discourse is quite limited due to the specificity of the left-right identification which has not yet been freed from the post-war and independence rhetoric. On the other hand, other studies reflect either a strongly center-right identification (Zuflaj, et al 2008: 47) or a non-manifested need to emphasize a clear ideological profile. Exception is made by Lëvizja Vetëvendosje!, an organization that is clearly challenging the whole system. In these conditions, in both cases we will look closely to some other factors which shape the radical left discourse like the organization profile, its political actions and its political opportunity structure.

In the case of Albania, radical left has been strongly contested in the beginning 
of the transition. The two major political parties, the Democratic and the Socialist Party, have both eventually constrained any chance of any radical left movements to emerge. For instance, in the last general elections of 2013, most of what can be possibly labeled as radical left parties, joined a coalition led by the Socialist Party, losing in such way any possibility to organize a viable political alternative to it. Furthermore, even members of radical left organizations, despite their radical statements, ended up actively or tacitly sustaining the left coalition.

In Kosovo, Vetëvendosje has been able to stand and thrive, successfully contesting the established post-war political party system. Due to the supervised statehood nature of post 2001 and 2007 of the country, Vetëvendosje has been able to impose a mixed nationalist - radical left agenda, (Kessler 2012) which has gained considerable support amongst the population. The origin of social movements is determined somehow by the respective closeness or openness of political institutions (Della Porta and Diani 1999), the availability of coalition partners that can help the movement and the possibility of the state to counter them. Yet, the case of Vetëvendosja Movement is quite particular to our account, since it managed to transform itself into a political party and it successfully participated in the 2010 elections, slowly changing its tactic towards a binary action: protest and political opposition within the parliament.

\section{Dynamics of conflict: Party system in Albania and Kosovo}

\section{Left transformed: the case of Albania}

The political party system in Albania may be best described as a partially frozen system. Since the first free elections in 1991, it has been dominated by two major political parties, the Socialist Party (the closer descendant to the previous communist party) and the Democratic Party (the main anticommunist political alternative). According to Kitchelt (1992), the dominant feature in the post-communist party systems has been the bipolarity between economic populism and market economy, blended with extensive references to anti-communism and post-communism. With the passing of time, the economic dimension has been blurred by the similarities, with the Socialist Party fully accepting market driven reforms (Fuga 2003: 17; Progni 2010: 266). The post-communist left in Albania underwent a normal, yet cautious transformation from 1991 onwards. Various authors (Lewis 2001; Bozoki and Ishiyama 2002; Leftwich Curry and Barth Urban 2003) have described these phenomena, common in post communist countries, as a form of identity change and adaptation. Zibblat (1998) has described two general strategies in 
this regard, namely leftist retreat offshoots or parties retaining their Marxist character and pragmatic reforms (social-democratization) or what can be later described as a run towards the center.

The Socialist Party of Albania in lieu of the pale social-democratic stance, has consistently and heavily relied in the political past and its accompanying nostalgia in order to mobilize its electorate (Ishiyama 2001). Both major Albanian parties are described either as catch-all (Stojarova 2010:181) or as structures contending rivalries running according to a north-south divide, the latter being linked not only to the geographical origin of the party leadership, but also to relevant electoral support (Xhaferaj 2011).

Contrary to many other cases, the anti-communist versus post-communist rhetoric still dominates the scene. The etiquettes of left and right gain their value when used in this sense, but also with regards to the ideological stance involving the continuity of the economic strategies, illustrated by the political debate on flat over progressive taxation sustained by the Socialist Party before the 2013 general political elections.

Despite the monopolization of the Albanian political scene by two major political parties, party system in Albania has evolved over time. The postcommunist left has shown a greater degree of instability in the last years, compared to what the Democratic Party experienced in the first decade of transition. While in the early stages of democratization, fragmentation has been a constant feature within the right political wing (Biberaj 2001; Krasniqi 2006)), the left has experienced some internal, yet substantial fragmentation, only in the period 2005-2009.

A second example of party formation as a result of major party fragmentation was provided by the creation of the Socialist Movement for Integration (hereinafter SMI), an offshoot of the major left party spectrum, the Socialist Party. The SMI has positioned itself as a social democratic party with only few differences from the Socialist Party. The SMI can be described as a highly pragmatic organization and has been considered as the 'king maker' in the last two general elections, swinging positions frequently and forming a majority government with the Democratic Party in 2009-2013 and with the Socialist Party from 2013 till present (2016).

The traditional left in Albania (the Socialist Party and the SMI) offers the same base identity regarding history and communist legacy, but the two parties differ to some degree over economic policy issues. Competition within the same ideological length, has ultimately constrained these parties to differentiate from one another. In this sense, the success of the SMI can be 
explained via two important features, its ability to distinguish itself in terms of ideological position vis-a-vis the Socialist Party and its ability to claim the guaranteeing of continuity and stability in a highly confrontational and unstable political system as Albania. In Kitchelt's classification (Kitchelt 2002:35) of the various communist parties in the East, Albania falls within the paternal communism category, implying in this way some sort of continuity in terms of consensus from the old regime to the new one. This statement can be further reinforced if we consider the low electoral volatility in Albania, coupled with a strong tendency towards voter identity transmission within Albanian families. Indeed, it is highly rare for Albanian family members to vote for a political party, different from the one favored by the head of the family (Këlliçi and Danaj 2009).

\section{The missing variable of the left: Party system in Kosovo}

For the purpose of this paper, we will focus on the main political parties, the most important ones created in the beginning of the 90s, and the biggest current parliamentarian parties. Due to object and space limitations, we will not go into details regarding all the political parties created in Kosovo after 1990.

The situation of political parties in Kosovo reflects some traits that are similar to the case of Albania, while at the same time maintaining some context and content specifics. Kosovo was part of the Federation of Yugoslavia at the end of the 80s. In 1989, the autonomy of Kosovo (a partial autonomy given by the FoY in 1974) was revoked, and Kosovo was at the time annexed under and completely dependent on the Republic of Serbia (Smajlaj, 2011: 73).

The peaceful resistance proclaimed by Ibrahim Rugova made him one of the most popular leaders of this period in Kosova, and also the unquestionable leader of the Democratic League of Kosovo (DLK) (Zuflaj et al, 2008:16). DLK, despite its decreasing popularity over time, has in fact been the most voted party in Kosovo elections until 2007. The peaceful resistance highly supported by the party and its leader Rugova at the beginning of the $90 \mathrm{~s}$, started to quickly lose ground as the situation in Kosovo was not improving (Danaj 2013).

In June 2000, after the war, another important party was created, namely the Democratic Party of Kosovo. It was mainly a party deriving from the important figures of the Kosovo Liberation Army. It can also be described as a "catch all party" as per categorization of political parties that have the maximizing of votes as their ultimate goal, with no specific clear inherent 
ideology (Williams 2009). The program of the Democratic Party of Kosovo, similar to its main political homologues in Albania, focuses considerably on the Kosovo accession to the European Union. While it remains quite difficult to evaluate the Albanian and Kosovo political parties in classical typology terms, we see that they refer mainly to the typology of "catch all parties" with the aim of EU integration becoming an integral part of this feature. Therefore, the emphasis on the EU integration cannot in itself be used as a proper element of clear ideological trait.

Two other relatively important current political parties in Kosovo are the Alliance for the Future of Kosovo and the New Kosovo Alliance, both created after the war. The first party was created in 1999 by one of the most popular Kosovo Liberation Army commanders, Ramush Haradinaj, while the second one was created in 2006 by a well-known businessman, Behgjet Pacolli, known for favoring free market economy, advancement of capitalism and a laissez faire welfare state.

The two parties do not however clarify any ideological orientation in their programs. This in turn constantly allows them to include various elements in their programs depending on the relevant election context. Ideology has had a slight assertive role in Kosovo, let alone any mention to left or marxism ${ }^{4}$.

As can be seen, the spectrum of the political parties created after 1989 in Kosovo is mainly related to the reaction of the dismantling of Yugoslavia, the annexing of Kosovo by Serbia, and to the post-war developments. The period before 1997 (the starting of the Kosovo war) was dominated by two main opposing ideologies, peaceful resistance versus armed resistance. After the War, the political spectrum changed due to the international presence in Kosovo, (that still continues through the presence of EULEX) and the emergence of new parties.

At the same time, there have been some attempts from scholars and activists to develop some form of critical and leftist thinking in Kosovo, but the latter has consisted mostly on translating leftist books and articles, "disseminating

\footnotetext{
4 "The demonization of the communism is mainly based on the economic failures of the socialist system applied before 1990. The universities have almost banned Marx from the curricula, while other important authors in various disciplines are almost unknown because of being Marxists or radicals [...] The critical theory is almost missing, while the opinion is led in a very superficial way towards imported media models from the Berlusconian media. "Communist" is a very fashionable offense, as is the labeling as "an anarchist". In Kosovo we have to also add to this, the association of "Communism" or "Socialism" or "Leftism" with the harsh Serb regime, or with Yugoslavia, where Albanians were treated as second-hand citizens...". Arbër Zaimi interview, 2013 (date)
} 
them among themselves" (Hoppe, 2013) or presenting them in the media. With this in mind, it is not possible to talk about organized left activists, but simply about "independent intellectuals" (Zaimi 2013). While claiming to be radical leftists, their social and political activity remains quite confined to the media (Zaimi, 2013).

\section{Left radical perspectives in Albania and Kosovo}

Nostalgia, civil engagement and cooptation: Embryonic radical left in Albania

Radical left organizations may fall in three general categories: parties, organizations and subcultures (March and Mudde 2005). In Albania such organizations can be categorized in two major groups: left hard line Marxist parties, disillusioned with the transformations of the Labor Party into the Socialist Party and radical left wing neo-Marxist groups like the Antonio Gramsci Institute or the OP. Interestingly enough, the perception for the radical left existence in Albania is strongly related to the second group rather than the first, with opinions describing them as "embryonic intellectual groups" (Hasimja 2013) or 'messianic groups of individuals, nostalgic of the Marxist rhetoric' (Mile 2013).

The first category is composed of three parties formed at various stages from 1992 to 2009, by hard line nostalgic former communists, the aim of which is basically the reevaluation of the former regime, which in turn is symbolized by the 'reevaluation' of the figure of the former communist dictator Enver Hoxha. They fall within the group of 'conservative communists' or 'orthodox communists' (March 2009; Bozòki and Ishyama 2002: 7) who do not wish to relinquish the past and who continuously dismiss the present capitalistic system.

Radical leftism does not necessarily reflect an opposition to democracy (March and Mudde 2005) but rather an opposition to the current economic system and the social disparities, the dismissal of the private sphere in the name of the public one. Despite the radical left rhetoric in Albania, its ideological position did not appeal to those disillusioned with the post-communist economic reforms. On the other hand, nostalgia sentiments enshrined in radical left parties are limited to symbols rather than to a substantial return to the past.

The difficulties encountered by the post-communist radical left may be summarized in three main aspects: a- the communist legacy that was wholly transmitted to the Socialist Party in terms of consensus and organization; 
b- the flexible behavior of the Socialist Party that partly relinquished its past and especially the memory related to the Liberation War; c- the initial suppression of the radical left Communist Party in the earlier years of the transition combined with the authoritarian tendencies (Vickers 2001: 240) of the Democratic Party, in power from 1992 to 1997 . The political opportunity structure remained weak in a period of deterioration of the political struggle and confrontation between the Democratic Party government and the Socialist Party opposition, culminating in the fall of the pyramid schemes and the occurrence of civil turbulence and anarchy in 1997.

Other factors have influenced the lack of success of the official radical left in Albania, such as the quasi-majoritarian tendency of electoral systems in Albania that has 'suffocated' small parties or forced them to merge in broad bipolar coalitions distributed along the left-right axis. Despite showing a strong anti- establishment character, all three radical ${ }^{5}$ left parties joined a coalition with the Socialist Party in the last elections while at the same time maintaining their radical agenda. Furthermore, their electoral performance has been insignificant, due also to the high degree of polarization of the Albanian traditional party system actors such as the Socialist and Democratic Parties, that does not leave room for extremist parties to surface, despite their convergence in terms of programs and despite their "catch all" character. Theoretical perspectives suggest that where party systems tend to be convergent (March 2009), there is some room for extremist parties to emerge. The case of Albania might deviate from the above suggestions, due to two main factors: a- the very first founding elections and electoral systems have already shaped the characters of the main political actors, and b- major political parties are in control of a capillary patronage system that needs to be further explored (Gjevori 2013; Mile 2013).

The second pattern of radical left in Albania is expressed through new organizations, fashioned according to western models, such as the Antonio Gramsci Institute, the OP or Occupy Tirana group. They differ from the traditional radical- left in two aspects: first through their ability to reference a less Orthodox type of Marxism mostly to younger generations, with no personal experiences related to the past (Hasimja 2013) and second, through their refusal to evolve into a more structured political party.

\footnotetext{
${ }^{5}$ Three parties maybe labeled as radical in Albania: Partia e Punës e Rinovuar (The Renovated Party of Labur of Albania), the Partia e Punës (Labour Party) and Partia Komuniste (Communist Party). Rregjistri i Partive, Komisioni Qëndror i Zgjedhjeve, http://www.cec. org.al/images/stories/zgjedhje-per-kuvend/2013/DJ\%20-\%20REGJISTRI\%20PARTIVE.pdf (last consulted 30.12.2013)
} 
The second group of radical left organizations, such as the OP falls in the category of the civil society. The above organization offers a practical example of the attempt to create a radical left initiative in Albania. Its vision departs from basic ideas of justice and equality, by aiming to 'fight for the public over private interests' (Marka 2013). It tries to create a political space capable of questioning the whole economic liberalism which, according to the organization, has had 'pervert consequences' for the whole Albanian society from the very beginning of the transition process (OP Manifesto 2011). OP seeks to represent and organize marginalized groups of society, mainly those left aside by the development of capitalism in the country. Its basic idea of social organization emphasizes the idea of public property and equal distribution of resources (OP Manifesto 2011), stressing the necessity of state property over the economic apparatus and full employment of workers. Another distinctive feature of the OP is what can be labeled as 'economic nationalism', a feature that, albeit of a minor presence in the traditional political discourse of the left, has gained some momentum during the economic crisis years. The latter has become also a distinctive feature of the radical left elsewhere in Western Europe (Halikiopoulou, Nanou and Vasilopoulou 2012), where the EU integration process is opposed by both, radical left and right, albeit from two distinctive perspectives. The OP in Albania does not question the idea of EU integration, but looks at it more in terms of 'people integration' rather than economic integration.

With regards to the social activism in Albania and civil society in general, they appear to suffer from the same symptoms as elsewhere in Eastern Europe. The fall of communism coincided with the demise and withdrawal of the state from public and individual life, leaving huge gaps open for addressing many social problems linked with the transition (Amy and Gjermeni 2013). Civil society is highly dependent on international donors and many of the issues they bring forth are more connected to the agenda of the donors, rather than expressing the needs of the society. In this sense, the OP regards the civil society as a quasi-bureaucratic entity, highly fragmented, incapable of expressing the needs of the people, unless it derives from forms of selforganization. Despite this vision of civil society, the organization has always tried to support initiatives that fall in its radical left agenda, such as worker rights, human rights and ecological issues.

At the same time, civil society protests have not gained much consensus amongst the general population. Probably the most successful civil engagement has been the protest movement against the destruction of Syrian chemical weapons in Albania. The protest began by a group of green organizations 
involving different segments of the society, with the OP actively participating in it. The protest was considered the most important of this kind, as it opened a path which "had seemed closed' for the left (Zaimi 2013).

There is also a different perspective on regarding protests as political actions in Albania. If we consider the second decade of post communism from 2000 onwards, we are unable to locate significant autonomous protest activity, be it supported or led by the civil society. The general characteristic of protests in Albania has been the 'appropriation' by political parties of the themes and action of such protests. In this sense, political parties have been able to control, to organize or to devaluate the protests as such. Some scholars attribute either a conservative nature to the protests in Albania, or a depoliticized nature in terms of affiliation with broader political and social demands (Mile 2011; Hoppe 2013).

Despite the above, the radical left in Albania has succeeded to surface and impose the inclusion of some problems in the agenda of the non-radical left. For instance, issues such as progressive taxation, the reduction of the number of private education institutions, or the abolition and control of state concessions in the mining sector, were inserted by the Socialist Party in its electoral program also due to the pressure coming from the radical left. While the OP did not fully support the Socialist Party, due to its deep suspicion on the latter's real intentions, the inclusion of the above issues in the political agenda, was an indication of some form of revival of re-ideologization in the left spectrum in the Albanian political arena.

Apart from the above, another pattern of 'collaboration' with the official left in Albania, has been the system of active cooptation or transmigration of civil society to political parties and vice versa, a relation that continues to be very active in the country (Amy and Gjermeni 2013; Elezi 2011). As regard to this relation dynamics, it is important to note the risk of political parties in Albania being able to exploit and devoid the civil society, not only of its intellectual and expertise capacities, but also of the truthfulness of its message. For instance, some active members of the OP in Albania have become government officials in the actual so called 'left' wing governing coalition'.

Lastly, with regards to social international activism, the latter cannot be

\footnotetext{
${ }^{6}$ This article has been written in 2014. As per 2016, it must be said that the OP has continued to make its discourse visible by diversifying its activities (undertaking research about workers' rights related issues, opposing the ongoing privatization policies of the Socialist Party leaded government, throwing eggs or tomato sauce toward the socialist prime minister and the socialist minister of education, etc.). http://www.dritare.net/2016/05/18/
} 
considered an integral part of either the OP in particular or the radical left in general in Albania.

\section{Radical left-nationalism in Kosovo: The case of Vetëvendosje}

Vetëvendosje is a political movement turned into political party, currently the third most voted in Kosovo, and the winning party of the last local elections in the capital Prishtina. Referring to Albin Kurti (the leader of Vetëvendosja), the difference between a political movement and a political party, is that while a movement is more dynamic, a party is quite static ${ }^{8}$. As he himself has stated: "We are not a classic political party. It's a movement. We think that representative democracy is not enough-direct participatory democracy ensures a more vibrant society. Representative democracy is illegitimate, it creates alienation and limits choice." (Albin Kurti in Nosan, 2012)

The origins of Vetëvendosje can be found at $\mathrm{KAN}^{9}$ (Kosova Action Network) activities and actions. The activities of KAN after the war were focused on finding the missing people, documenting the war crimes, and, in the beginning of the 2000s, focusing against the activity of UNMIK (the UN mission in Kosovo based on the resolution 1244). In 12 June 2005 the building of UNMIK, but also other buildings in other parts of Kosovo, were filled with the slogan "No negotiations - Self-determination". This was the moment of transformation of KAN to Vetëvendosje (Lëvizja Vetëvendosje,

ekskluzive-gjyq-kunder-vezes-mbi-kryeministrin/1; http://www.exit.al/en/2016/11/18/student-activist-mirela-ruko-on-her-action-and-resistance-against-neo-liberalization-of-higher-education/;

http://ikesh.org/wp-content/uploads/2016/04/Gjendja-e-klasës-punëtore-në-Shqipëri-(I).pdf ${ }^{7}$ For the historical part and also the elements of the program of Vetëvendosje, we have used the official documents that may be consulted in the Vetëvendosje website, accessed on December $30^{\text {th }} 2013$, : www. Vetëvendosje.org

${ }^{8}$ Meeting with students at the European University of Tirana, December 2011.

9 "Founded in 1997, by a group of international activists led by American writer Alice Mead, now Alice W. James, KAN at the start supported citizens' initiatives against the occupation and dictatorship of Serbia in Kosovo, such as the case of support for the Independent Union of Students of the University of Prishtina (UPSUP) and their non-violent protest for the release of their buildings and spaces in the university. It continued with documentation of crimes during the war, and reached its culmination during the years 1999 and 2000 with the A-PAL (Albanian Prisoner Advocacy list) campaign for the release of war hostages. In July of 2003, it was decided that KAN should be based inside of Kosovo and it was to create a network there. Since that time, with the considerable participation of activists from all over Kosovo, KAN organized a series of activities in order to strengthen individuals all over Kosovo, and to create a dynamic and representative society”. History of Lëvizja Vetëvendosje! (Movement for Self-Determination!), 2010, www.Vetëvendosje.org, consulted the $20^{\text {th }}$ of November 2013). 
2010). Vetëvendosje continued with the protests mainly against the process of negotiations aimed at offering to Kosovo a special status, but still not the so wanted independence. Even though the movement was structurally based on a very collegial form of organization, Albin Kurti was profiled at the time as the leader of Vetëvendosje. ${ }^{10}$ Vetëvendosje continued its protests, considering EULEX (established in 2008 after the proclamation of independence of Kosovo) as just a "replacement of UNMIK and criticizing Albanian leaders for being servants of the international presence" (IKS, 2011: 55). In 2010, Vetëvendosje decided to participate in the general elections, becoming the third voted party after Democratic Party of Kosovo and the Kosovo Democratic Alliance gaining, 12 seats in the Parliament.

The unification with Albania is another element of Vetëvendosje program. According to Kurti (in Nosan, 2012) Kosovo "should have that right [of unification to Albania], but we are not allowed to vote on it. Article 1.3 of the Constitution of Kosovo does not allow Kosovo to join another country (meaning Albania). They took this from Austria. Article 4 of Austria's constitution forbids Austria to join Germany. But wait a minute; it was not we who had Hitler, it was Serbia who had Milošević. There should be a place for referendums on this. People should have the right to vote". The quest for the right of unification to Albania, the struggle of Vetëvendosje against the hegemony of products from Serbia (while Serbia does not allow products from Kosovo to enter the country), as well as the wave of privatizations done with the blessing of the international community in Kosovo (Augestad Knudsen, 2010) are considered as the nationalistic dimension of Vetëvendosje. According to Halikiopoulou, Nanou and Vasilopoulo (2012) the radical left and right wing parties in Europe are not very "dissimilar" to each other as

10 "Kurti was arrested on the day of the protest and was kept in jail until July 2007 after which he was put under house arrest, a restriction which was lifted on 19 December 2007. During this period Kurti was prohibited from leaving his apartment or contacting Vetëvendosje or the media. Kurti then refused to obey court summons saying that the whole process was politically motivated. The process was suspended however on 7 February 2008 as six defending lawyers had refused to represent Kurti in court.

With the declaration of independence in February 2008, the case was transferred from UNMIK to the newly established European Rule of Law Mission in Kosovo, EULEX. After two years in suspension, the case was then revived on 15 February 2010. Kurti was to show up in front of the jury on the same indictment. It was only after Kurti's refusal to come to court and failure of appointed defending lawyers to show up, that the Kosovo police arrested him on 12 June 2010. Two days later, the EULEX-appointed judge Ferdinando Boatier de Mangeot, handed down a decision sentencing Kurti to nine months in prison. He was immediately released however due to the fact that he had already spent a combined 11 months in prison and house arrest in 2007', IKS, 2011: 55. 
they have a common denominator such as nationalism and euroscepticism. If we try to see Vetëvendosje in this perspective, the situation is however a little different. It is quite difficult indeed to make generalizations of the leftist or the nationalist dimension of Vetëvendosje, given the specifics of Kosovo politics. According to Hoppe (2013), "Vetëvendosje has always shown that it is against the one way trade agreements that allow Serbian or Macedonian merchandise into Kosovo but not Kosovo products to be exported in these surrounding countries. ... but is this considered "nationalism?". If we review the protests or the program of Vetëvendosje, the focus is put on the lack of reciprocity and equality of Kosovo in the agreements and resolutions after 1999. According to Zaimi (2013) "the radical critique that Vetëvendosje makes to the actual regime in Kosovo includes the international dimension too, such as the UN, EU and the U.S., and also the geo-economy that reduces Kosovo in a periphery, in a market of last hand, similar to the former colonies in the Eastern Asia or Africa. This radical critique puts Vetëvendosje intellectually and philosophically in the left of the spectrum"11.

Vetëvendosje openly opposes the privatization of public enterprises considering that these are assets for the country's future economic development (IKS, 2011). It has organized and participated in many protests against the privatization of state owned enterprises, in cooperation with trade unions, civil society organizations and citizens. Vetëvendosje has supported several protests of trade unions, farmers students, as well as protests organized by women's organizations such as regarding the law about the victims of rape during war, etc. (Zaimi 2013).

Despite the above analysis, it remains difficult to build a typology of the left in Kosovo, even though the program and the actions of Vetëvendosje are clearly positioned in the left side of the political spectrum. According to Albin Kurti (in Nosan, 2012) Kosovo, "is not a proper state with proper political parties and institutions, so you cannot have left or right. It is more complex than that. It is like talking about what kind of ingredient you want to use for a pie when you don't even have the fireplace to make the pie with, in the first place."

\footnotetext{
11 The left nationalist, as an emancipatory vector (national-liberating) remains very important in the countries that officially or not officially still functions as colonies, and with a denied right of self-determination. Also, there is a certain left nationalism in the programs of the left parties such as SYRIZA, Die Linke, or Front de Gauche. This type of nationalism is expressed as a critique toward the neoliberal globalisation, ... the new even worst frontiers between the center and the periphery, or between the superpowers and the servants. This type of liberating nationalism contains inside the seads for a healthy internationalism, based not on the extermination of the other, but on the respect of reciprocity and equality as the only premisses that brings to the collaboration and cohabitation (Zaimi, 2013).
} 
This is an important statement to highlight the complexity of the situation in Kosovo, if one aims to typify the left and radical left there. The whole case of Vetëvendosje is very important in order to show not only the complexity of the situation in Kosovo, but also the complexity of talking about left and right and nationalism. As we have already stated above, it is quite difficult to come up with clear-cut typologies of the left and right in Kosovo, due to the necessity to consider the specifics of the country, and the difficulty of finding an answer as to why such a movement as Vetëvendosje, with a clear social-democratic program, is often considered as a nationalistic movement. In this case, it is important to deconstruct the nationalistic dimension of Vetëvendosje and see if this is really nationalism in the traditional sense, such as hostility towards the others or isolationism? Or should this nationalistic dimension be considered more in the frame of the new geo-economy and inequalities between the center and periphery, or in the frame of the national liberation of colonies? While analysis of such issues remains important, they are subjects of further reflections that go beyond the limited scope and space of this article.

\section{Conclusions}

We have tried to show through this paper, that there are radical left wing movements in Albania and Kosovo, if we refer to radical left as movements and organizations that are against the neoliberalism and the underlying socioeconomic structure of contemporary capitalism and that don't reflect opposition to democracy (March and Mudde 2005). At the same time, it is quite complex to establish a properly defined typology of the left in Albania and Kosovo, even though there are some similarities between the two. The similarities observed are related mostly to the fact that there is a lack of development of left organisations and parties in Albania and Kosovo and their perceived relation to the communist past. Another common element can be observed in the fact that the big parties in both countries (apart from Vetëvendosje) fit quite well in the format of "catch all" parties, adapting their programs to the electoral circumstances. There are currently important organizations that belong to the left of the spectrum in both countries, although in the case of Kosovo this is more visible via the activities of the Vetëvendosje Movement that is currently the third most voted party in Kosovo and the leading party in the capital Prishtina. While it is difficult to trace any left identity in other political parties in Kosovo, Vetëvendosje presents a clear left program based on the development of the public sphere, the creation of the welfare state, opposition of mass privatisation, strengthening solidarity and equality, etc. At 
the same time, Vetëvendosje is also a movement with a significant nationalistic dimension that should not be seen as a chauvinist hostile attitude towards the others, but rather as a quest for equality in relation to other countries, and as a denouncement of the new geo-economic and geo-political inequalities. In this sense, further analysis and research are needed in order to provide a more in depth understanding of the "left nationalism", rather than jumping into simplistic conclusions that an organisation with nationalistic elements cannot be fully left. On the other side, radical left in Albania is not as well-organized as Vetëvendosje, neither in number nor in activities or actions, and it remains quite confined to the capital of the country. However, one of the successes of the current radical left organisations in Albania can be considered their pressure made to the biggest self-called left party in Albania to introduce left wing elements such as progressive taxation and stronger protection of workers' rights (even though such policies were used only for electoral purposes). Contrary to Vetëvendosje that is a movement of action appealing more to civil society as well as a parliamentarian party, hence completely different from other traditionally structured parties, the radical left in Tirana is organised in the form of civil society organisations and has suffered from the co-optation of its members by the big political parties. Lastly, a final impediment to the growth of radical left movements in Albania, remains the frequent fragmentation of civil society (Amy and Gjermeni 2012). While this paper has analysed some of the major traits of the left and radical left in Kosovo and Albania, as well as their respective similarities and differences, there is certainly a necessity for further in-depth analysis and research.

\section{References}

- Amy, L. E. \& Gjermeni, E. (2013). Where is the 'State' in Albania? The Unresolved Contradictions Confronting Civil Society 'Transition' from Communism to Free Markets. Studies of Transition States and Societies, 5(1), 7-21

- Augestad Knudsen, R. (2010). Privatization in Kosovo: The International Project 1999-2008, Oslo: NUPI Norwegian Institute of International Affairs.

- Biberaj, E. (2001). Shqipëria në Tranzicion: Rruga e Vështirë drejt Demokracisë. Tirana: Botime Ora

- Bòzoki, A. \& Ishiyama, J. (2002). The Communist Successor Parties in Central and Eastern Europe. New York-London: M.E. Sharpe

- Chiodi, L., Martino, F. \& Vanoni, F. (2008). From one parallel society to another. Osservatorio Balcani e Caucaso, Occasional Paper, 1-17

- Della Porta. D. and Diani. M. 1999. Social Movements: An Introduction. 
Malden MA: Blackwell Publishing.

- De Waal, C. (2005). Albania today: A portrait of post-communist turbulence. London: I.B. Tauris.

- Elezi, G. (2013). Ndërveprimi midis partive politike dhe organizatave të shoqërisë civile. Polis, 11, 48-61

- Fischer, B. J. (2005). L'Anschluss italiano. La guerra in Albania (1939-1945), Nardó: Besa Editrice

- Flick, U. (1998). An introduction to qualitative research. London: Sage

- Fuga, A. (2003) Majtas jo djathtas. Tirana: Botime ORA

- Halikiopoulou, D., Nanou, K. \& Vasilopoulo, S. (2012). The paradox of nationalism: The common denominator of radical right and radical left euroscepticism. European Journal of Political Research, 51, 504-539

- IKS. (2011). A Power Primer, A Handbook to Politics, People and Parties in Kosovo. Prishtina: Kosovo Stability Initiative,

- Ishiyama, J. (2001). Party Organization and the political success of the communist successor parties. Social Sciences Quarterly, 82 (4), 844-861

- Kanzleiter, B., \& Tomic, D. (2012). The left in the post-Yugoslav area. In B. Daiber, C. Hildebrandt, \& A. Striethorst, From revolution to coalition - radical left parties in Europe (pp. 309-325). Berlin: Rosa-Luxemburg-Foundation.

- Kajsiu, B. (2008). Vdekje Politikës, Liri Popullit!-Kriza e Përfaqësimit në Përgjithësi. Polis, 5-25.

- Kessler-Vardari, A. (2012). Politics of Protest in Supervised Statehood: Co-Shared Governance and Erosion of Citizenship. The Casestudy of the Vetëvendosje! Movement in Kosovo. Southeastern Europe, 36, 149-177

- Këlliçi, K. (2010). A ka vend për skemën Lipset-Rokkan në Shqipëri?. Politikja, 2, 193-208

- Këlliçi, K. \& Danaj, E. (2011). Përcaktuesit e pjesmarrjes politike të të rinjve: E majta dhe e djathta. Polis, 10, 103-120

- Kitchelt, H. P. (1986). Political Opportunity Structures and Political Protest: Anti Nuclear Movements in Four Democracies. British Journal of Political Science, 16 (1), 57-85

- Kitchelt, H. P. (1992). The Formation of Party Systems in East Central Europe. Politics and Society, 20 (1), 7-50

- Kitchelt, H. P. (2002). Constraints and Opportunities in the Strategic 
Conduct of Post-Communist Successor Parties: Regime Legacies as Causal Argument. In: Bòzoki, A. \& Ishiyama, J. (eds.) The Communist Successor Parties in Central and Eastern Europe, (pp. 14-40). New York-London: M. E. Sharpe.

- Krasniqi, A. (2009). Zgjedhjet në Shqipëri. Tirana

- Krasniqi, A. (2006). Partitë Politikë në Shqipëri. Tirana

- Leftwich Curry, J. \& Barth Urban, J. (2003). The Left Transformed in Post-Communist Societies: The Cases of East-Central Europe, Russia and Ukraine Oxford-New York: Rowman \& Littlefield Publishers.

- Lewis, P. G. (2001). Political Parties in Post-Communist Eastern Europe, London: Routledge

- Lëvizja Vetëvendosje! (2010). History of Lëvizja Vetëvendosje! (Movement for Self-Determination!). Accessed on December 3, 2013, www. Vetëvendosje.org

- Lëvizja Vetëvendosje! (2013) Alternativa Qeverisëse (Governing Alternative), Accessed December 3, 2013, www.Vetëvendosje.org

- March, L., \& Mudde, C. (2005). What's left of the radical left? The european radical left after 1989: Decline and mutation. Comparative European Politics , 3, 23-49

- March, L. (2008). Contemporary Far Left Parties in Europe: From Marxism to Mainstream?. International Policy Analysis, Berlin: Fredrich Ebert Stiftung, http://library.fes.de/pdf-files/id/ipa/05818.pdf

- Mair, P. (1997). Party System Change: Approaches and Interpretations, Oxford: Oxford University Press

- Meyer, D. S. \& Staggenborg, S. (1996). Movement, Countermovement and, the Structure of Political Opportunity. The American Journal of Sociology, 101 (6), 1628-1660

- Mile, K. (2013). Protesta si Fenomen Konservator. Polis, 11, 30-47

- Nosan, B. (2012). Kosovo's Vetëvendosje Movement Doesn't Like Foreign Intervention. Accessed on 20 December 2013,

- http://www.vice.com/read/kosovos-Vetëvendosje-movement-doesnt-like-foreign-intervention

- Organizata Politike (2013). Statuti i Organizatës Politike 2013 (Statute of Political Organization), Tirana: OP

- Organizata Politike. (2013). Manifesti i Organizatës Politike (Political Organization Manifesto), Tirana: OP

- Progni, L. (2010). Trashëgimtarët. Tirana: UET Press

- Rootes, C. (1999). Political Opportunity Structures: Promise, problems and prospects. La Lettre de la maison Française d'Oxford, Nr. 10, 75-97

- Smajlaj, A. (2011). Ailing the Process: Political Parties and Consolidation of Democracy in Kosovo. Dissertation, Universität Duisburg-Essen. 
Accessed November 12

- http://duepublico.uni-duisburg-essen.de/servlets/DerivateServlet/Derivate-27290/Smajljaj_Dissertation_pdf.pdf

- Stojarova, V. (2010). The Party System of Albania. In: Stojarova, V, \& Emerson, P. (eds.) Party Politics in the Western Balkans, London: Routledge

- Offe, K. (1991). Capitalism by Democratic Design? Democratic Theory Facing the Triple Transition in East Central. Europe Social Research, Vol. 58 , Nr. 4, 865-892,

- Vickers, M. (2000). The Albanians: A Modern History. London: I.B. Tauris

- Williams, M. H. (2009) Catch-all in the Twenty-first Century? Revisiting Kirchheimer's Thesis 40 years Later: An Introduction. Party Politics, 15, 539-541.

- Xhaferaj, E. (2011) Party system and social cleavages: the case of post-communist Albanian Elections. PECOB Paper Series, Nr. 10, Accessed 20 November. 2013, http://www.iecob.net/main/pecobs-papers-series/289party-system-and-social-cleavages-the-case-of-the-post-communist-albanian-elections-by-endri-xhaferaj

- Zibblat, D. (1998). The Adaptation of Ex-Communist Parties to Post-Communist East Central Europe: Comparative Study of the Hungarian and East German Ex-Communist Parties. Communist and Post-Communist Studies, 31(2), 119-137

- Zulfaj J., Mulliqi, B., Shala, M., \& Tahiri, P. (2008) Political Parties in Kosova, Profile and Ideology. Prishtinë: Çelnaja

- Interviews

- Danaj, K., Regional Political Analyst, Center for Political and Social Prognosis, Tirana, December 3, 2013.

- Gjevori, E., Ph.D. candidate, Dublin City University, December 17, 2013

- Hasimja, E., Lecturer of Political Communication, University of New York Tirana, November 27, 2013

- Hoppe, A., Lecturer of Anthropology, John Jay College for Criminal Justice, December 12, 2013

- Marka, J., Organizata Politike, November 30, 2013

- Mile, K., Lecturer of Political Science, European University of Tirana, December 2, 2013

- Zaimi, A., Political Committees' Coordinator at Lëvizja Vetëvendosje, December 12, 2013 